\title{
Variation in environmental parameters in research and aquaculture: effects on behaviour, physiology and cell biology of teleost fish
}

\begin{abstract}
Over the last few years the increasing use of fish as animal models in scientific research and the increased fish breeding for human consumption have stressed the need for more knowledge on the effect of variations in environmental parameters on fish biology and on the welfare of specimens used both in research and aquaculture contexts. Experimental evidence shows that environmental variations can affect fish biology at various levels, from the molecular to that of the population, sometimes in a different way depending on the species considered. In order to achieve reproducible results in experiments involving fish it is necessary to set and maintain all environmental parameters constant at the optimal value to guarantee the wellness of the animal. The effects of the variation in environmental parameters on the behaviour, physiology and cell biology of teleosts are here discussed in order to provide useful information for research based on fish models.
\end{abstract}

Keywords: Environmental parameters, Teleost fish, Welfare, Aquaculture, Research
Volume 5 Issue 6 - 2017

\author{
Mattia Toni,' Elisa Angiulli,' Stefano Malavasi,' \\ Enrico Alleva, ${ }^{3}$ Carla Cioni' \\ 'Department of Biology and Biotechnology \\ 2Dipartimento di Scienze Ambientali, Informatica e Statistica, \\ CEMAS, Center for Estuarine, Italy \\ ${ }^{3}$ Department of Cell Biology and Neuroscience, Istituto \\ Superiore di Sanit
}

Correspondence: Mattia Toni, Department of Biology and Biotechnology, Tel +390649918005,

Emailmattia.toni@uniromal.it

Received: June 05, 2017 | Published: June 13, 2017
Abbreviations: ASR, Aquatic Surface Respiration; CNS, Central Nervous System

\section{Introduction}

A close relationship between the environment and living beings has always existed. Since the peculiar environmental conditions on our planet have enabled the development of life, the environmental parameters strongly influence the biological processes and simultaneously the biological activity modifies the environment. The variation in biotic and abiotic environmental factors induces responses in animals at multiple levels from the molecular, cellular, organismic and population levels.

When animals are kept in captivity in a non-natural environment, it is essential to control and regulate the environmental parameters to ensure conditions not only compatible to the animal's life but which ensure the welfare of animals by preventing the state of suffering

The scientific research takes advantage of animal models whose utilization can be strongly reduced by in vitro cell culture systems, but currently it cannot be completely eliminated.

In animal housing for the purpose of research, the control and standardization of environmental parameters is crucial to ensure not only the welfare of animals, but also the quality and reproducibility of the scientific outcome. The variation in any biotic and abiotic environmental parameter can potentially induce physiological responses in the animal that may affect the experimental results. Depending on the species considered, the knowledge of the effects of such variations may be more or less incomplete, and therefore not completely predictable. The report of the experimental results must therefore be accompanied by a precise and detailed description of all the environmental parameters to which the animal has been subjected during housing and the experimental phases in order to be able to replicate exactly the same environmental conditions.

Recently, the use of teleost fish in research has increased sharply also aided by the acquisition and application of the principle of Relative replacement suggesting wherever possible the use of animal with a simpler central nervous system.
The environmental parameters that need to be taken into account in relaying fish are the quality and supply of water, the dissolved oxygen, the $\mathrm{pH}$ level, the presence of nitrogenous compounds, the environmental salinity, the temperature, the light intensity and the darklight alternation cycle, the noise in term of intensity and frequency of sound waves, the stocking density, the environmental complexity, the feeding, and finally the handling and killing procedures (Figure 1), as stated also in European Directive 2010/63/EU.

The researcher who uses teleost fish models, as well as aquaculture farmers, must know as much as possible the effects induced on the animal by variation in environmental parameters. This review provides an overview on the current understanding of the effects of changes in single environmental parameters on the behaviour, physiology and cell biology of teleost fish, in order to provide a useful tool for research groups that use models of fish or who approach for the first time the use of this model.

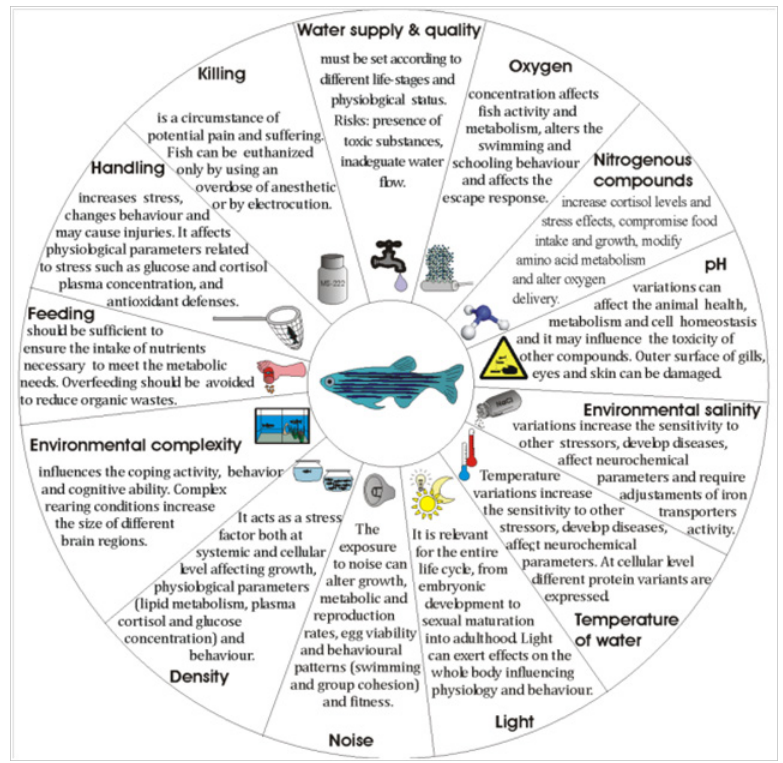

Figure I Environmental parameters that must be considered to ensure the welfare of the fish in research and aquaculture context. 


\section{Environmental parameters}

\section{Water supply and quality}

Water supply and quality are important abiotic parameters that must be considered to ensure fish welfare. Fish raised in aquaria or in laboratory husbandry facilities have more or less reduced volumes of water available in comparison to a natural environment, so that it becomes essential to monitor the water parameters to ensure stable, controlled conditions for fish welfare. Water quality must be also monitored in relation to the possible presence of toxic substances such as pollutants, metals, chlorine and ammonia and the water flow should be set to levels supporting normal swimming. Any changes in water quality and conditions should be gradually applied allowing fish to acclimatize and adapt to them. The relevance of acclimatization period is also stated in the European Recommendation on farmed fish, where the species-specific degree of adaptability to the water quality changes is underlined. Moreover, in the aquaculture context the complete life cycle of fish must be sustained. Therefore, water quality parameters shall be set and monitored in according to different life-stages (e.g. larvae, juveniles, adults) and physiological status (e.g. metamorphosis, spawning) of fish.

\section{Oxygen}

Fish, as all aerobic organisms, require oxygen for breathing The concentration of $\mathrm{O} 2$ dissolved in water affects fish activity and metabolism ${ }^{1}$ and alters the swimming behaviour ${ }^{2,3}$ with related effects on many aspects of fish life. Hypoxia can be caused by a variety of factors, including excess of nutrients and water bodies stratification due to saline or temperature gradients. Oxygen levels required depend on fish species, their ecological adaptation to hypoxia ${ }^{3}$ and the metabolic rate of the animal at rest..$^{4-6}$ The behavioural response to acute hypoxia involves a balance between an increase in swimming activity, in search of more oxygenated waters, and a decrease in the same activity to reduce oxygen demands. ${ }^{7}$ A behavioural response adopted by some fish that frequently experience environmental hypoxia is to perform aquatic surface respiration (ASR), that consists in swimming close to the surface for ventilating the gills with the more oxygenated superficial water. This behaviour, however, exposes them to a greater risk of predators. Moreover, hypoxia affects the escape response of fish and their schooling behavior. ${ }^{8}$ In captivity, factors such as fish density, handling, water flow and temperature influence the levels of $\mathrm{O} 2$ available and its demand. ${ }^{9}$

\section{Nitrogenous compounds}

The concentration of nitrogenous compounds, derived as waste products from the amino acid catabolism, is another parameter to be considered in fish housing. In teleost fish, the most abundant nitrogen products of excretion are ammonia (sum of $\mathrm{NH} 3$ and $\mathrm{NH} 4+$ ) and urea. Ammonia is a highly toxic compound extremely soluble in water. Because of its toxicity, ammonia must be quickly and efficiently excreted by the organism or converted into a less toxic product. ${ }^{10}$ The relative amount of excreted ammonia and urea depends on the species and the life cycle. Most adult teleosts are ammonotelic since they produce and excrete ammonia as a result of deamination whereas juveniles of several fish species are ureotelic as they excrete nitrogenous waste in the form of urea. ${ }^{11-15}$ Fish diet is particularly rich in proteins that make a major contribution $(41-85 \%)$ to the total energy production of fishes ${ }^{16}$ and this determines the intake of high amounts of nitrogen containing amino acids. A direct relationship between protein intake and ammonia excretion was demonstrated in several species. For example, in salmon (Oncorhynchus nerka) an increased release of ammonia was measured after food intake. ${ }^{17}$ The ammonia is a highly toxic compound and extremely soluble in water. In aqueous solution, an equilibrium exists between its unionized $(\mathrm{NH} 3)$ and ionized form $(\mathrm{NH} 4+)$. The relative concentration of $\mathrm{NH} 3$ and $\mathrm{NH} 4+$ is not only dependent on the ammonia pKa (9.5), and thus on the hydrogen ion concentration, but also on temperature, pressure and other ions concentration..$^{18}$ The toxicity for the aquatic organisms is largely due to $\mathrm{NH} 3$, while the $\mathrm{NH} 4+$ gives only a minor contribution to the toxic events reported for ammonia. Because of its toxicity, the ammonia generated in the cells by the nitrogen catabolism must be quickly and efficiently excreted by the organism or converted into a less toxic product. ${ }^{10}$ Thus, the ammonia generated in the liver is released in the environment through gills, body surface and renal routes. The epithelium that best fulfils the role for ammonia excretion is the gill epithelium, whereas the epidermis and the kidney contribute to a lesser extent. At cellular level, the ammonia-transporting Rhesus $(\mathrm{Rh})$ proteins, a family related to methyl ammonia and ammonia transporters in bacteria, yeast and plants, were shown to mediate the excretion of ammonia from the gills (Rhag, Rhbg and Rhcg). ${ }^{15,19-23}$ In the aquaria, the ammonia released into the water accumulates reaching doses that may be dangerous for fish health. Indeed, the exposure to ammonia may cause several effects such as histopathological changes in gill structure ${ }^{24,25}$ increased cortisol levels and generalized stress effects ${ }^{26,27}$ compromised food intake and growth ${ }^{28}$ modified amino acid metabolism ${ }^{29,30}$ altered oxygen delivery, ${ }^{31}$ enzymes induction and impairment of ion exchange through the gills. ${ }^{16,32}$ For these reasons, in order to ensure the welfare of fish housed in animal facilities nitrogen compounds must be maintained at low concentrations.

\section{$\mathrm{pH}$}

Fish can survive in a narrow range of $\mathrm{pH}$ as its value strongly affects the metabolism and homeostasis of cells and the whole organism. The great majority of aquatic organisms live at $\mathrm{pH}$ 6.58.5 , which corresponds to the same range found in most freshwater lakes, streams, and ponds. $\mathrm{pH}$ variations out of this range can affect the animal health by damaging the outer surface of gills, eyes, and skin, and causing an inability to dispose of metabolic wastes. All this may eventually lead the animal to death. In aquaria, water $\mathrm{pH}$ has to be daily monitored and kept stable by controlling parameters related to its value. Indeed, the toxicity of some compounds may vary depending on the $\mathrm{pH}$ of the solution. For example, the percentage of ammonia in solution and its toxicity are strongly dependent on the water $\mathrm{pH}^{3}{ }^{33}$

\section{Environmental salinity}

Fishes can also tolerate different levels of environmental salinity. In both freshwater and marine fishes, there are species able to tolerate large variations in salt concentration, called euryhaline, and others that are not able to, called stenohaline species. In natural environments, euryhaline fish usually move among marine waters, estuaries, rivers and lagoons. On their way these fish experience gradual changes of salinity and their regulatory systems of ions and water (gills, digestive system, kidney) undergo structural and functional reorganizations in response to altered salinity. In particular, it has been shown that the acclimation to salinity requires adjustments of the activity and the abundance of ion transporters such as the sodium-potassium ATPase pump ${ }^{34-36}$ and GLUT1 $1{ }^{37}$ The acclimation process has energy costs and requires time for modifying protein expression at cellular level. ${ }^{28,38}$ Differently from the gradual ones, rapid changes in water salinity can have adverse effects even in euryhaline fish resulting in an increased sensitivity to other stressors (such as temperature changes and low 
oxide concentration) and diseases. ${ }^{39}$ Changes in salinity can also affect neurochemical parameters. ${ }^{40}$

For example, the decreased activity of acetylcholinesterase (AChE) is associated to increased activity of NTPDase (ADP hydrolysis) and 5 '-nucleotidase in the brain of silver catfish exposed to elevated salt concentrations. ${ }^{40}$

\section{Water temperature}

As regard the importance of the water temperature parameter, we have to consider that fish are ectothermic or poikilothermic organisms whose body temperature corresponds to water temperature. Each fish can live within a given range of temperatures characterized by a lower and an upper lethal value. ${ }^{41}$ This temperature range is species specific as a result of the evolution and the adaptation of the animal to its environment. Each species has an ideal temperature range within which it grows quickly and the standard environmental temperature is defined as the temperature that the fish would prefer if they could choose. ${ }^{9}$ Variations in ambient temperature strongly affect fish biology and influence growth rate, food consumption, feed conversion, physiology, behaviour along with other body functions. ${ }^{42-47}$ Recently, studies performed on juveniles and adults of European sea bass showed that acclimation temperature affects both behavioural responses and neurochemical parameters ${ }^{48,49}$ in the CNS (Central Nervous System). The metabolic rate of fish is sensibly affected by body/ ambient temperature: at lower values there is a drop in the metabolic rate, whereas at higher temperatures there is an increase which implies a greater need for food and oxygen ${ }^{50-52}$ The main response to thermal variation in fish is behavioural: in a natural environment fish are free to move to different areas or depths to find their optimal temperature. When unable to find the best temperature, fish attempt to maintain physiological rates by expressing protein and enzyme variants with different thermal characteristics and modifying protein environments to minimize the impact of temperature changes.$^{53} \mathrm{In}$ laboratory facilities, fish are bred in tanks without the possibility of choosing the preferred temperature. For this reason temperature must be maintained within the optimal range for each species and kept as stable as possible to avoid stress conditions and to ensure the welfare of animals and any changes in temperature must be applied gradually.

\section{Light}

The light and the day/night cycle regulate the environment and influence the life of all organisms. In teleost fish, light is relevant for the entire life cycle, from embryonic development to sexual maturation into adulthood. ${ }^{54}$ Land animals and fish are not necessary exposed to the same enlightenment as in the water the intensity and spectral composition of the light decreases with depth due to the absorption by water molecules and suspended particles. The water column acts as a chromatic filter rapidly absorbing wavelengths comprised between infrared and ultraviolet. As a result, shorter wavelengths of visible light (blue/violet) penetrate deeper through water than longer wavelengths (red/orange). So, depending on the depth at which the fish live, they are exposed to different lighting and the aquatic organisms have developed visual adaptation according to their spectrum niche. Moreover, in teleost fish the threshold of light intensity and sensitivity to light vary during the development. It has been demonstrated that there are differences in retinal morphology and cell composition among larval, juvenile and adult fish. ${ }^{55-57}$ For example, most marine fish larvae have only pure-cone retina at their early developmental stages, but later rods appear and the single-cone retina gradually transforms into a duplex retina. ${ }^{55,56}$ Fish are thought to have adapted their vision and retinal spectrum perception to their natural photo-environment ${ }^{58,59}$ containing rods and cones in accordance to the available wavelength range of their particular niche. ${ }^{60,61}$ Light influences human and animal life and physiological processes are generally synchronized with the solar day. For example, in humans basic functions such as sleep/ wake cycle, breathing rate, body temperature,${ }^{62}$ digestion, ${ }^{63}$ heartbeat and blood pressure are under circadian control. ${ }^{64}$ Other organisms, including fish, have developed timing mechanisms of adaptation to regular changes in sunlight. These mechanisms, called circadian clock, consist in regulatory networks made of feedback loops of transcription and translation. ${ }^{65}$ Data obtained in zebrafish have demonstrated that, as in other vertebrates, most fish tissues contain circadian clocks. ${ }^{66,67}$ The available data suggest that light can exert effects on the whole body of fish. In fact, it has been demonstrated that in zebrafish the direct illumination of cells activates the expression of a subset of clock genes and that this in turn leads to circadian clock entrainment. ${ }^{66,68-72}$ The presence of opsins, the photopigments usually contained in retinal photoreceptors, has been recently demonstrated also in the peripheral tissues of Danio rerio.$^{73}$ Overall, these data indicate that, unlike mammals, fish do not rely only on their eyes to perceive light as their whole body may be capable of detecting light.

In fish, ambient light conditions may affect behavioural patterns such as schooling, shoaling, foraging, feeding and locomotion. ${ }^{74-77}$ Besides, light is crucial in behavioural interactions such as predatorprey encounters. ${ }^{78,79}$ As to the importance of the photoperiod in fish physiology, fish must be maintained under appropriate photoperiod where natural light does not allow a suitable light/dark cycle and controlled lighting with an intensity adapted to the reared species must be provided to satisfy biological requirements.

\section{Noise}

The noise is another parameter that should be considered in fish welfare. In aquatic environments noise can be produced by both biotic (animal and plant sounds), abiotic (wind, rain, running water, waterfall), and antropogenic (engine and sonar of boats, ships and submarines and construction sites) sources and fish can be exposed to a wide range of noise intensity. Potential effects of sound on fish probably depend on characteristics such as level, duration, spectrum and also on the hearing capacity of the species of interest, as all fish are not equally able to perceive sound. Teleost fish can be separated into two non-taxonomic groups based on their sensitivity to sound: hearing specialists and hearing generalists. ${ }^{80}$ The hearing specialists, such as the goldfish, have small bony connections (Weberian ossicles) or other structures that bridge the swim bladder with the inner ear, enabling these species to detect higher frequency sounds. Hearing generalists, which are the majority of fish species, lack these specialized connections and only perceive frequencies below $500-1000 \mathrm{~Hz} .{ }^{80} \mathrm{In}$ fish, the apparent effects of sound can range from undetectable or subtle behavioural changes up to severe physiological effects causing deafness and death. ${ }^{81}$ Intense noise (over $140 \mathrm{~dB}$ ) in fish may induce temporary hearing loss, ${ }^{82-85}$ damage in the inner ear sensory epithelium ${ }^{86,87}$ and endocrine stress responses. ${ }^{85,88,89}$

Recent experimental works showed that noise exposure can alter some behavioural patterns in fish, such as swimming behaviour, swimming speed and group cohesion. ${ }^{90,91}$ As pointed out by Slabbekoorn and co-workers, ${ }^{92}$ there are many aspects concerning the effects of noise on aquatic life, that are still to be extensively investigated in order to assess properly the relationships between the type and level of noise, the behavioural effects and the consequences for the reproductive success of fish. This indicates that, both for aquaculture and laboratory research, the experimental studies on noise 
effects are still at an early stage, in order to provide proper welfare guidelines.

Equipment used in aquaculture, such as aerators, pumps, filtration systems, cascading streams associated with recirculation systems can increase the noise to which the animals are subjected ${ }^{80,93,94}$ and this may well result in a significant reduction in growth and reproduction rates, higher metabolic rates, increased mortality and lower egg viability. ${ }^{85,95-97}$ As noises and vibrations are efficiently transmitted in water and they can act as stressors for fish, it is mandatory to consider them during experimental design to ensure the validity of the data obtained. Noise levels in husbandry facilities, including ultrasounds, must not adversely affect animal welfare. Also, alarm systems must sound outside the sensitive hearing range of the animals, while not impairing their audibility by human beings. If necessary, holding rooms must be provided with noise insulation.

\section{Stocking density}

Density is another factor that must be taken into account in fish husbandry. Most of the studies conducted to understand the effect of density on fish growth and welfare have been performed on juvenile or adults, given also the interest of fish farms in identifying the optimum density at which to rear animals. Among the fish analysed we can mention rainbow trout (Oncorhynchus mykiss), ${ }^{98}$ salmon (Salmo salar), ${ }^{99}$ gilthead sea bream (Sparus aurata), ${ }^{100}$ pike perch (Stizostedion lucioperca) ${ }^{101}$ Tilapia nilotica,${ }^{102}$ arctic charr (Salvelinus alpinus) ${ }^{103}$ African catfish (Clarias gariepinus) ${ }^{104}$ summer flounder (Paralichthys dentatus), ${ }^{105}$ dover sole (Solea solea), ${ }^{106}$ Californian halibut (Paralichthys californicus), ${ }^{107}$ ningu (Labeo victorianus), ${ }^{108}$ catfish (Mystus cavasius), ${ }^{109}$ pufferfish (Takifugu obscures), ${ }^{110}$ and tub gurnard(Chelidonichthys lucerna). ${ }^{111}$ Together, these studies have shown species-specific effects of high density that in some species reduce the growth performance of fish ${ }^{106,107,112,113}$ while in other species have no effect upon reproduction. ${ }^{105,114-116}$ The species-specific effect is probably dependent on different physiological response to stress, increased social interactions and different sensitivity of fish to the deterioration of water quality. ${ }^{113,117-122}$ Indeed, high density can strongly affect water parameters resulting in a reduction of oxygen availability and a higher concentration of ammonia. ${ }^{108}$

The high density may act as a stress factor both at systemic and cellular level. Inappropriate density can affect different physiological parameters in fish altering the lipid metabolism ${ }^{118,123}$ increasing the concentration of plasma cortisol ${ }^{16,124}$ and glucose ${ }^{118}$ and decreasing the peritoneal leukocyte cytotoxicity. ${ }^{125}$ Moreover, at high density an increase of aggressive or cannibalistic behaviour in ocellate puffer larvae was reported. ${ }^{126}$ Recent studies in Takifugu obscurus have shown that the high density determines an over-expression of genes considered biomarkers of stress such as those coding for HSP 70, HSP 90B, metallothionein, cytochrome P450 1A and phosphoenolpyruvate carboxykinase. ${ }^{110}$ These results show that the high density is a stress factor causing a delay in the growth of the animal. ${ }^{110}$ It has been assumed that coping with stress increases the overall energy demand, which is then unavailable for growth. ${ }^{127}$ On the other hand, decreased feed consumption, ${ }^{123}$ social interaction ${ }^{121}$ and altered water quality ${ }^{128}$ may result in increased metabolic demands and additional expenditure of energy at the expense of growth.

The stocking density of fish shall be based on the total needs of the fish in respect to environmental conditions, health and welfare. Fish must have access to a volume of water that allows normal swimming and is consistent with their size, age, health and feeding method. Moreover, the introduction or re-introduction of animals to established groups shall be carefully monitored to avoid problems of incompatibility and disrupted social relationships. Furthermore, an adequate stocking density shall permit minimizing the risk of injures and stress and to promptly identify and remove moribund or dead fish. In a breeding facility, the density of fish shall be also appropriate to the ability to maintain a correct water quality and consistent with the feeding system.

\section{Environmental complexity}

The presence of physical elements in the tank, acting as barriers and covers, or sand for some flatfish, may facilitate both the recognition of different individual areas and the reduction of aggressive encounters. The use of appropriate enrichment techniques should allow to extend the range of activities available to the animals and to increase their coping activities including physical exercise, foraging, manipulative and cognitive activities, as appropriate to each species. Environmental enrichment in animal enclosures must be adapted to the species and individual needs of the animals concerned. Moreover, complex rearing conditions increase the size of different brain structures such as cerebellum, telencephalon and optic tectum ${ }^{129,130}$ making animals more skilful to cope with environment. Fish must be provided with appropriate environmental enrichments such as hiding places or bottom substrate to allow the expression of a wide range of normal behaviours. For more information on all issues concerning the environment enrichment for fish in captive environments, see the recent review article authored by Näslund \& Johnsson. ${ }^{131}$

\section{Feeding}

Feeding is another issue to be considered and the amount and quality of food should be sufficient to ensure the intake of calories and nutrients necessary to meet the metabolic needs of the animal without producing excessive waste in the aquatic system. As to feeding, fish show a wide variability and are generally grouped as herbivorous, carnivorous, detritivorous and omnivorous on the basis of their food habits and they can be further subdivided into plankton feeders, benthic invertebrate feeders and fish feeders. ${ }^{132-135}$ In fish, acquisition of food is a process based on different sensory systems that usually involves searching, detection, capture and ingestion. Different sensory cues including vision, chemoreception, acoustic, lateral line and electroreception may contribute to aspects of the feeding behaviour in fish. Among species, differences in role and significance of the sensory systems are also present. ${ }^{136}$ Vision is crucial for the initial detection of the prey and the orientation to it. Furthermore, the lateral line contributes to determine the optimum distance and angular deviation for the initiation of a rapid strike toward the prey. ${ }^{137}$ Besides, both olfaction and gustation, two sensory systems that respond to amino acids, can play a dominant role in food detection in many fish species. ${ }^{136-138}$ The type and composition of the diet may influence food conversion and growth rate. In particular, differences have been reported in fish fed with natural or artificial diets that could be attributed to the lower protein and higher carbohydrate content of an artificial diet when compared with a natural one. ${ }^{139-143} \mathrm{As}$ regard the amount of food, fish overfeeding results in the production of large amounts of particulate organic wastes in the form of waste feed and faecal matter that can contribute to water deoxygenation and to the production of reduced compounds such as ammonium and sufides. ${ }^{144}$ Moreover, studies demonstrate that overfeeding affect the feed conversion energy depending on fish species and environmental condition. ${ }^{145}$ On the other hand, the underfeeding can cause an increase in the interfish competition and in the number of attack events that can cause injuries to the animals. ${ }^{146,147}$ The time of day when the fish are 
fed is a parameter that must be considered as it may affect growth, food conversion efficiency ${ }^{142,148-151}$ and even animal behaviour. This influence may be hormonally mediated ${ }^{148}$ and the ghrelin hormone plays an important role in the control of food intake. In fish, as in other vertebrates, ghrelin is a peptide that shows an orexigenic, or appetite stimulating, effect as its administration increases food intake. ${ }^{152}$ The release of ghrelin increases under fasting conditions and decrease after feeding ${ }^{153,154}$ suggesting a role for this hormone in regulating food assumption in fish. Ghrelin acts activating other orexin systems such as the neuropeptide $\mathrm{Y}$ and orexin. ${ }^{155} \mathrm{In}$ fish, ghrelin is also involved in the modulation of locomotor activity. ${ }^{135,156,157}$ In particular, it has been proposed that ghrelin is involved in the generation of food anticipatory activity as the increase in locomotor activity was observed 3-4 h before food supply in scheduled fed animals, including goldfish. ${ }^{158}$

Taken together the above information emphasize the wide variability in feeding modalities in fish and the significant influence of the diet composition and the timing of food administration on fish growth and behaviour. For these reasons, fish must be fed with a suitable diet at an appropriate feeding rate and frequency, and that particular attention must be given to feeding larval fish during any transition from live to artificial diets. Furthermore, all fish have to get access to feed to avoid undue competition, especially for fry and young fish.

\section{Handling}

Fish handling is another parameter that needs to be considered in fish welfare. Various studies conducted on different fish species have shown that handling may affect different physiological parameters related to stress such as glucose and cortisol plasma concentration ${ }^{159,160}$ may negatively influence the antioxidant defences ${ }^{161}$ may affect the blood lactate concentration and haematocrit and, finally, fish growth. ${ }^{162}$ On the basis of these scientific information, fish handling has to be kept to a minimum. The handling should be carried out only when necessary in a farm too. The stakeholder shall behave to make as much as possible limited the stress of fish. Equipment and procedure used shall be chosen to minimize stress and injury. The sedation or anaesthesia may be appropriate. Moreover, everything shall be made to handle fish in the water, if fish have to be taken out of the water, this shall be done in the shortest time possible and equipment in direct contact with body fish shall be moistened. Additionally, in order to correctly handling a fish, it shall be entirely supported and not be lifted by individual body parts only, such as the gill covers.

\section{Fish killing}

The killing of fish is a circumstance of potential pain and suffering for animals. Recommendations are given for farming fish bred in Europe in order to the killing is on spot and without delay by a person properly trained and experienced. The method used shall cause immediate death, rapidly render the fish insensitive or cause the death when fish is anaesthetized or effectively stunned. Parameters such as immediate and irreversible cessation of respiratory movements and the loss of eye roll reaction shall be monitored as indicator of death occurred. If large groups of fish have to be killed for emergency as disease control, the effectiveness of procedure shall be evaluated on a sample, and just in this case, carbon dioxide might be used. In the Directive 2010/63/EU the modalities by which fish must be sacrificed are listed in the Annex IV, where it is specified that fish can be euthanized only by using an overdose of anesthetic or by electrocution.

\section{Conclusion}

The chemical-physical parameters of the natural aquatic environment can vary widely depending on the geographic location and the type of area considered. Each species of fish have adapted during evolution to live in specific environmental conditions and they respond to environmental variations moving toward areas with more suitable characteristics.

In fish housing practices, that they are for research or aquaculture purposes, it is essential to know the effects of environmental parameters on the fish in order to provide the animal an optimal environment to live, which ensures the well-being of animal avoiding suffering.

The knowledge of the effects of environmental parameters on animal's biology and the availability of suitable equipment to keep these parameters constant is a prerequisite to obtain repeatable experimental data in scientific research and to ensure a healthy food product with high organoleptic quality in aquaculture context.

\section{Acknowledgements}

We thank Dr. Arianna Manciocco for the help in the manuscript preparation. This study was supported by Sapienza University of Rome [Progetti di Ricerca 2016] and by FIRB Futuro in ricerca 2012 (RBFR12QW4I_002).

\section{Conflicts of interst}

None.

\section{References}

1. Lefrancois C, Claireaux G. Influence of ambient oxygenation and temperature on metabolic scope and scope for heart rate in the common sole Solea solea. Mar Ecol Prog Ser. 2003;259:273-284.

2. Steffensen JF, Farrell AP. Swimming performance, venous oxygen tension and cardiac performance of coronary-ligated rainbow trout, Oncorhynchus mykiss, exposed to progressive hypoxia. Comp Biochem Physiol A Mol Integr Physiol. 1998;119(2):585-592.

3. Fitzgibbon Q, Strawbridge A, Seymour R. Metabolic scope, swimming performance and the effects of hypoxia in the mulloway, Argyrosomus japonicus (Pisces: Sciaenidae). Aquaculture. 2007;270(1):358-368.

4. McCarthy I. Temporal repeatability of relative standard metabolic rate in juvenile Atlantic salmon and its relation to life history variation. J Fish Biol. 2000;57(1):224-238.

5. Nespolo RF, Franco M. Whole-animal metabolic rate is a repeatable trait: a meta-analysis. J Exp Biol. 2007;210(11):2000-2005.

6. Broggi J, Hohtola E, Koivula K, et al. Long-term repeatability of winter basal metabolic rate and mass in a wild passerine. Funct Ecol. 2009;23(4):768-773.

7. Lefrançois C, Ferrari R, Moreira Da Silva J, et al. The effect of progressive hypoxia on spontaneous activity in single and shoaling golden grey mullet Liza aurata. J Fish Biol. 2009;75(7):1615-1625.

8. Domenici P, Lefrancois C, Shingles A. Hypoxia and the antipredator behaviours of fishes. Phil Trans R Soc. 2007;362(1487):2105-2121.

9. Johansen R, Needham JR, Colquhoun DJ, et al. Guidelines for health and welfare monitoring of fish used in research. Lab Anim. 2006;40(4):323340

10. Randall DJ, Ip YK. Ammonia as a respiratory gas in water and airbreathing fishes. Respir Physiol Neurobiol. 2006;154(1-2):216-225.

11. Barimo JF, Steele SL, Wright PA, et al. Dogmas and controversies in the handling of nitrogenous wastes: ureotely and ammonia tolerance in early life stages of the gulf toadfish, Opsanus beta. J Exp Biol. 2004;207(12):2011-2020. 
12. Chadwick TD, Wright PA. Nitrogen excretion and expression of urea cycle enzymes in the atlantic cod (Gadus morhua 1.): a comparison of early life stages with adults. J Exp Biol. 1999;202(19):2653-2662.

13. Essex Fraser PA, Steele SL, Bernier NJ, et al. Expression of four glutamine synthetase genes in the early stages of development of rainbow trout (Oncorhynchus mykiss) in relationship to nitrogen excretion. J Biol Chem. 2005;280(21):20268-20273.

14. Steele SL, Chadwick TD, Wright PA. Ammonia detoxification and localization of urea cycle enzyme activity in embryos of the rainbow trout (Oncorhynchus mykiss) in relation to early tolerance to high environmental ammonia levels. J Exp Biol. 2001;204(12):2145-2154.

15. Wright $\mathrm{P}$, Felskie A, Anderson P. Induction of ornithine-urea cycle enzymes and nitrogen metabolism and excretion in rainbow trout (Oncorhynchus mykiss) during early life stages. J Exp Biol. 1995;198(1):127-135.

16. Mommsen TP, Vijayan MM, Moon TW. Cortisol in teleosts: dynamics, mechanisms of action and metabolic regulation. Rev Fish Biol Fish. 1999;9(3):211-268.

17. Brett J, Zala C. Daily pattern of nitrogen excretion and oxygen consumption of sockeye salmon (Oncorhynchus nerka) under controlled conditions. J Fish Res Board Can. 1975;32(12):2479-2486.

18. Emerson K, Russo RC, Lund RE, et al. Aqueous ammonia equilibrium calculations: effect of $\mathrm{pH}$ and temperature. J Fish Res Board Can. 1975;32(12):2379-2383.

19. Nakada T, Westhoff CM, Kato A, et al. Ammonia secretion from fish gill depends on a set of Rh glycoproteins. FASEB J. 2007;21(4):1067-1074.

20. Shih TH, Horng JL, Hwang PP, et al. Ammonia excretion by the skin of zebrafish (Danio rerio) larvae. Am J Physiol Cell Physiol. 2008;295(6):1625-1632.

21. Weihrauch D, Wilkie MP, Walsh PJ. Ammonia and urea transporters in gills of fish and aquatic crustaceans. J Exp Biol. 2009;212(11):17161730 .

22. Nawata CM, Wood CM, O'Donnell MJ. Functional characterization of Rhesus glycoproteins from an ammoniotelic teleost, the rainbow trout, using oocyte expression and SIET analysis. J Exp Biol. 2010;213(7):1049-1059.

23. Hwang PP, Lee TH, Lin LY. Ion regulation in fish gills: recent progress in the cellular and molecular mechanisms. Am J Physiol Regul Integr Comp Physiol. 2011;301(1):28-47.

24. Flis J. Anatomicohistopathological changes induced in carp (Cyprinus carpio L.) by ammonia water. Part II. Effects of subtoxic concentrations. Acta hydrobiol. 1968;10:225-238.

25. Smart G. The effect of ammonia exposure on gill structure of the rainbow trout (Salmo gairdneri). J Fish Biol. 1976;8(6):471-475.

26. Spotte S, Anderson G. Plasma cortisol changes in seawater-adapted mummichogs (Fundulus heteroclitus) exposed to ammonia. Can J Fish Aquat Sci. 1989;46(12):2065-2069.

27. Tomasso J, Davis KB, Simco BA. Plasma corticosteroid dynamics in channel catfish (Ictalurus punctatus) exposed to ammonia and nitrite. Can J Fish Aquat Sci. 1981;38(9):1106-1112.

28. Beamish F, Tandler A. Ambient ammonia, diet and growth in lake trout Aquat Toxicol. 1990;17(2):155-166.

29. Arillo A, Margiocco C, Melodia F, et al. Ammonia toxicity mechanism in fish: studies on rainbow trout (Salmo gairdneri Rich.). Ecotoxicol Environ Safety. 1981;5(3):316-328.

30. Levi G, Morisi G, Colettp A, et al. Free amino acids in fish brain: norma levels and changes upon exposure to high ammonia concentrations in vivo, and upon incubation of brain slices. Comp Biochem Physiol $A$ Physiol. 1974;49(4):623-636.
31. Sousa RJ, Meade TL. The influence of ammonia on the oxygen delivery system of coho salmon hemoglobin. Comp Biochem Physiol A Physiol. 1977;58(1):23-28.

32. Claiborne JB, Evans DH. Ammonia and acid-base balance during high ammonia exposure in a marine teleost (Myoxocephalus octodecimspinosus). J Exp Biol. 1988;140(1):89-105.

33. Delos C, Erickson R. Update of ambient water quality criteria for ammonia. EPA/822/R-99/014. Final/Technical Report. DC: US Environmental Protection Agency, USA. 1999.

34. Marshall WS. $\mathrm{Na}+, \mathrm{Cl}-, \mathrm{Ca} 2+$ and $\mathrm{Zn} 2+$ transport by fish gills: retrospective review and prospective synthesis. $J$ Exp Zool. 2002;293(3):264-283

35. Evans DH, Piermarini PM, Choe KP. The multifunctional fish gill: dominant site of gas exchange, osmoregulation, acid-base regulation, and excretion of nitrogenous waste. Physiol Rev. 2005;85(1):97-177.

36. Tang $\mathrm{C}$, Lee $\mathrm{T}$. The effect of environmental salinity on the protein expression of $\mathrm{Na}+/ \mathrm{K}+-$ ATPase, $\mathrm{Na}+/ \mathrm{K}+/ 2 \mathrm{Cl}-$ cotransporter, cystic fibrosis transmembrane conductance regulator, anion exchanger 1 , and chloride channel 3 in gills of a euryhaline teleost, Tetraodon nigroviridis. Comp Biochem Physiol A Comp Physiol. 2007;147(3):521-528.

37. Balmaceda-Aguilera C, Martos-Sitcha JA, Mancera JM, et al. Cloning and expression pattern of facilitative glucose transporter 1 (GLUT1) in gilthead sea bream Sparus aurata in response to salinity acclimation. Comp Biochem Physiol A Mol Integr Physiol. 2012;163(1):38-46.

38. Lin Y, Chen C, Yoshinaga T, Tsai S, Shen I, et al. Short-term effects of hyposmotic shock on $\mathrm{Na}+/ \mathrm{K}+-$ ATPase expression in gills of the euryhaline milkfish, Chanos chanos. Comp Biochem Physiol A Comp Physiol. 2006;143(3):406-415.

39. Birrer SC, Reusch TB, Roth O Salinity change impairs pipefish immune defence. Fish Shellfish Immunol. 2012;33(6):1238-1248.

40. Becker AG, Parodi TV, Gonçalves JF, et al. Ectonucleotidase and acetylcholinesterase activities in silver catfish (Rhamdia quelen) exposed to different salinities. Biochem Syst Ecol. 2013;46:44-49.

41. Beschta RL, Bilby RE, Brown GW, Holtby LB, Hofstra TD Stream temperature and aquatic habitat: fisheries and forestry interactions. In: Salo EO, Cundy TW (Eds.), Streamside Management: Forestry and Fishery Interactions. Institute of Forest Resources, University of Washington, Seattle, pp. 1987;191-232.

42. Houlihan D, Mathers E, Foster A Biochemical correlates of growth rate in fish. In: Fish ecophysiology. Springer, pp. 1993;45-71.

43. Britz PJ, Hecht T, Mangold S Effect of temperature on growth, feed consumption and nutritional indices of Haliotis midae fed a formulated diet. Aquaculture. 1997;152(1):191-203.

44. Azevedo PA, Young Cho C, Leeson S, Bureau DP Effects of feeding level and water temperature on growth, nutrient and energy utilization and waste outputs of rainbow trout (Oncorhynchus mykiss). Aquat Living Resour. 1998;11(4):227-238.

45. Stoner A Effects of environmental variables on fish feeding ecology: implications for the performance of baited fishing gear and stock assessment. J Fish Biol. 2004;65(6):1445-1471.

46. Claireaux G, Couturier C, Groison A-L Effect of temperature on maximum swimming speed and cost of transport in juvenile European sea bass (Dicentrarchus labrax). J Exp Biol. 2006;209(17):3420-3428.

47. Sfakianakis D, Georgakopoulou E, Papadakis I, et al. Environmental determinants of haemal lordosis in European sea bass, Dicentrarchus labrax (Linnaeus, 1758). Aquaculture. 2006;254(1-4):54-64.

48. Malavasi S, Cipolato G, Cioni C, Torricelli P, Alleva E, et al. Effects of temperature on the antipredator behaviour and on the cholinergic expression in the European sea bass (Dicentrarchus labrax L.) juveniles. Ethology. 2013;119(7):592-604. 
49. Manciocco A, Toni M, Tedesco A, et al. The acclimation of European Sea Bass (Dicentrarchus labrax) to temperature: behavioural and neurochemical responses. Ethology. 2015;121(1):68-83.

50. Clarke A Costs and consequences of evolutionary temperature adaptation. Trends Ecol Evol. 2003;18(11):573-581.

51. Person-Le Ruyet J, Mahe K, Le Bayon N, et al. Effects of temperature on growth and metabolism in a Mediterranean population of European sea bass, Dicentrarch;us labrax. Aquaculture. 2004;237(1):269-280.

52. Neuheimer A, Thresher R, Lyle J, et al. Tolerance limit for fish growth exceeded by warming waters. Nat Clim Change. 2011;1(2):110-113.

53. Hochachka PW, Somero GN. Biochemical Adaptation. University Press, USA, pp. 2014;1-560.

54. Villamizar N, Blanco-Vives B, Migaud H, et al. Effects of light during early larval development of some aquacultured teleosts: A review. Aquaculture. 2011;315(1):86-94.

55. Kvenseth A, Pittman K, Helvik J. Eye development in Atlantic halibut (Hippoglossus hippoglossus): differentiation and development of the retina from early yolk sac stages through metamorphosis. Can J Fish Aquat Sci. 1996;53(11):2524-2532.

56. Helvik JV, Drivenes Ø, Naess TH, et al. Molecular cloning and characterization of five opsin genes from the marine flatfish Atlantic halibut (Hippoglossus hippoglossus). Vis Neurosci. 2001;18(5):767780 .

57. Bejarano-Escobar R, Blasco M, DeGrip WJ, et al. Cell differentiation in the retina of an epibenthonic teleost, the Tench (Tinca tinca, Linneo 1758). Exp Eye Res. 2009;89(3):398-415.

58. Kusmic C, Gualtieri P. Morphology and spectral sensitivities of retinal and extraretinal photoreceptors in freshwater teleosts. Micron. 2000;31(2):183-200.

59. Chinen A, Matsumoto Y, Kawamura S. Reconstitution of ancestral green visual pigments of zebrafish and molecular mechanism of their spectral differentiation. Mol Biol Evol. 2005;22(4):1001-1010.

60. Bowmaker J. Visual pigments of fishes. In: Douglas R, Djamgoz M (Eds.), The Visual System of Fish. Springer, Netherlands, pp.1990;81107.

61. Partridge JC, Cummings ME. Adaptation of visual pigments to the aquatic environment. In: Archer SN \& Djamgoz MBA, (Eds.) Adaptive Mechanisms in the Ecology of Vision. Springer, Netherlands. 1999;pp.251-283.

62. Schmidt C, Collette F, Cajochen C, et al. A time to think: circadian rhythms in human cognition. Cogn Neuropsychol. 2007;24(7):755-789.

63. Dallmann R, Brown SA, Gachon F. Chronopharmacology: new insights and therapeutic implications. Annu Rev Pharmacol Toxicol. 201454:339-36.

64. Brown SA. Circadian clock-mediated control of stem cell division and differentiation: beyond night and day. Development. 2014;141(16):31053111

65. Shigeyoshi Y, Taguchi K, Yamamoto S, et al. Light-induced resetting of a mammalian circadian clock is associated with rapid induction of the mPerl transcript. Cell. 1997;91(7):1043-1053.

66. Whitmore D, Foulkes NS, Sassone-Corsi P. Light acts directly on organs and cells in culture to set the vertebrate circadian clock. Nature. 2000404(6773):87-91.

67. Schibler U, Sassone-Corsi P. A web of circadian pacemakers. Cell. 2002;111(7):919-922.

68. Vallone D, Gondi SB, Whitmore D, et al. E-box function in a period gene repressed by light. Proc Natl Acad Sci. 2004;101(12):4106-4111.

69. Ziv L, Levkovitz S, Toyama R, et al. Functional development of the zebrafish pineal gland: light-induced expression of period2 is required for onset of the circadian clock. J Neuroendocrinol. 2005;17(5):314 320 .

70. Tamai TK, Young LC, Whitmore D. Light signaling to the zebrafish circadian clock by Cryptochrome 1a. Proc Natl Acad Sci. 2007;104(37):14712-14717.

71. Hirayama J, Cho S, Sassone-Corsi P. Circadian control by the reduction/ oxidation pathway: catalase represses light-dependent clock gene expression in the zebrafish. Proc Natl Acad Sci. 2007;104(40):1574715752.

72. Mracek $\mathrm{P}$, Pagano $\mathrm{C}$, Fröhlich $\mathrm{N}$, et al. ERK signaling regulates light-induced gene expression via D-Box enhancers in a differential, wavelength-dependent manner. PLoS ONE. 2013;8(6):e67858.

73. Ramos BC, Moraes MNC, Poletini MO, et al. From blue light to clock genes in zebrafish ZEM-2S cells. PloS ONE. 2014;9(9):e106252.

74. Cahill GM, Hurd MW, Batchelor MM. Circadian rhythmicity in the locomotor activity of larval zebrafish. Neuroreport. 1998;9(15):34453449 .

75. Batty R, Blaxter J, Richard J. Light intensity and the feeding behaviour of herring, Clupea harengus. Mar Biol. 1990;107(3):383-388.

76. Ryer CH, Olla BL. Effect of light on juvenile walleye pollock shoaling and their interaction with predators. Mar Ecol Prog Ser. 1998;67:215226

77. John KR, Haut M. Retinomotor cycles and correlated behavior in the teleost Astyanax mexicanus (Fillipi). J Fish Res Board Can. 1964;21(3):591-595.

78. Emery AR. Preliminary comparisons of day and night habits of freshwater fish in Ontario lakes. J Fish Res Board Can. 1973;30(6):761774

79. Hobson ES. Interactions between piscivorous fishes and their prey Predator-prey systems. In H. Clepper (Ed.), Fisheries management. Sport Fishing Institute, USA, pp. 1979;231-242.

80. Popper AN. Effects of anthropogenic sounds on fishes. Fisheries $2003 ; 28(10): 24-31$

81. Wysocki LE, Davidson JW III, Smith ME, et al. Effects of aquaculture production noise on hearing, growth, and disease resistance of rainbow trout Oncorhynchus mykiss. Aquaculture. 2007;272(1):687-697.

82. Popper AN, Clarke NL. The auditory system of the goldfish (Carassius auratus): effects of intense acoustic stimulation. Comp Biochem Physiol A Comp Physiol. 1976;53(1):11-18.

83. Scholik AR, Yan HY. Effects of underwater noise on auditory sensitivity of a cyprinid fish. Hear Res. 2001;152(1):17-24.

84. Amoser S, Ladich F. Diversity in noise-induced temporary hearing loss in otophysine fishes. J Acoust Soc Am. 2003;113(4):2170-2179.

85. Smith ME, Kane AS, Popper AN. Noise-induced stress response and hearing loss in goldfish (Carassius auratus). $J$ Exp Biol. 2004;207(3):427-435.

86. Hastings MC, Popper AN, Finneran JJ, et al. Effects of low-frequency underwater sound on hair cells of the inner ear and lateral line of the teleost fish Astronotus ocellatus. J Acoust Soc Am. 1996;99(3):17591766 .

87. Enger PS. Frequency discrimination in teleosts-central or peripheral? In: Hearing and sound communication in fishes. Springer. 1981;pp.243255.

88. Sverdrup A, Kjellsby E, Krüger P G, et al. Effects of experimental seismic shock on vasoactivity of arteries, integrity of the vascular endothelium and on primary stress hormones of the Atlantic salmon. $J$ Fish Biol. 1994;45(6):973-995. 
89. Santulli A, Modica A, Messina C, et al. Biochemical responses of European sea bass (Dicentrarchus labrax L.) to the stress induced by off shore experimental seismic prospecting. Mar Pollut Bull. 1999;38(12):1105-1114.

90. Neo YY, Parie L, Bakker F, et al. Behavioral changes in response to sound exposure and no spatial avoidance of noisy conditions in captive zebrafish. Front Behav Neurosci. 2015;9:28.

91. Shafiei Sabet S, Neo YY, Slabbekoorn H. The effect of temporal variation in sound exposure on swimming and foraging behaviour of captive zebrafish. Anim Behav. 2015;107:49-60.

92. Slabbekoorn H, Bouton N, van Opzeeland I, et al. A noisy spring: The impact of globally rising underwater sound levels on fish. Trends Ecol Evol. 2010;25(7):419-427.

93. Bart A, Clark J, Young J, et al. Underwater ambient noise measurements in aquaculture systems: a survey. Aquacult Eng. 2001;25(2):99-110.

94. Richardson WJ, Greene Jr CR, Malme CI, et al. Marine mammals and noise. Academic press, San Diego, USA, pp. 2013;1-452.

95. Lagardère J. Effects of noise on growth and reproduction of Crangon crangon in rearing tanks. Mar Biol. 1982;71(2):177-185.

96. Banner A, Hyatt M. Effects of noise on eggs and larvae of two estuarine fishes. T Am Fish Soc. 1973;102(1):134-136.

97. Regnault M, Lagardère JP. Effects of ambient noise on the metabolic level of Crangon crangon (Decapoda, Natantia). Mar Ecol Prog Ser. 1983;11(1):71-78.

98. Trzebiatowski R, Filipiak J, Jakubowski R. Effect of stock density on growth and survival of rainbow trout (Salmogairdneri Rich.). Aquaculture. 1981;22:289-295

99. Gardiner R, Shackley P. Stock and recruitment and inversely densitydependent growth of salmon, Salmo salar L., in a Scottish stream. J Fish Biol. 1991;38(5):691-696.

100. Canario AV, Condeca J, Power D, et al. The effect of stocking density on growth in the gilthead sea-bream, Sparus aurata (L.) Aquac Res. 1998;29(3):177-181.

101. Molnár T, Hancz C, Bódis M, et al. The effect of initial stocking density on growth and survival of pike-perch fingerlings reared under intensive conditions. Aquac Int. 2004;12(2):181-189.

102. Carro-Anzalotta AE, McGinty AS. Effects of stocking density on growth of Tilapia nilotica cultured in cages in ponds. $J$ World Aquacult Soc. 1986;17(1-4):52-57.

103. Christiansen JS, Svendsen YS, Jobling M. The combined effects of stocking density and sustained exercise on the behaviour, food intake, and growth of juvenile Arctic charr (Salvelinus alpinus L.). Can J Zool. 1992;70(1):115-122.

104. Kaiser H, Weyl O, Hecht T. The effect of stocking density on growth, survival and agonistic behaviour of African catfish. Aquac Int 1995;3(3):217-225.

105. King N, Howell WH, Fairchild E. The effect of stocking density on the growth of juvenile summer flounder Paralichthys dentatus. In: Nutrition and Technical Development in Aquaculture. Proceedings of the 26th US-Japan on Aquaculture Symposium, Durham, NH, USA pp.1997;173-180

106. Schram E, Van der Heul J, Kamstra A, et al. Stocking density-dependent growth of Dover sole (Solea solea). Aquaculture. 2006;252(2):339-347.

107. Merino GE, Piedrahita RH, Conklin DE. The effect of fish stocking density on the growth of California halibut (Paralichthys californicus) juveniles. Aquaculture. 2007;265(1):176-186.

108. Mokoro A, Oyoo-Okoth E, Ngugi CC, et al. Effects of stocking density and feeding duration in cage-cum-pond-integrated system on growth performance, water quality and economic benefits of Labeo victorianus (Boulenger 1901) culture. Aquac Res. 2014;45(10):16721684.

109. Rahman M, Zaher M, Azimuddin KM, et al. Stocking density effects on growth and production of the threatened silurid catfish, Mystus cavasius (Hamilton) fingerlings in nursery ponds. Aquac Res. 2013;44(7):1132-1139.

110. Kim JH, Dahms HU, Han KN. Biomonitoring of the river pufferfish, Takifugu obscurus in aquaculture at different rearing densities using stress-related genes. Aquac Res. 2013;44(12):1835-1846.

111. Roncarati A, D'Andrea M, Pilla F, et al. Tub gurnard Chelidonichthys lucerna L.: a new fish species suitable for farming? First answers evaluating the growth of juveniles reared at different stocking densities, welfare and fillet quality. Aquac Res. 2013;44(7):1140-1151.

112. Irwin S, O'halloran J, FitzGerald R. Stocking density, growth and growth variation in juvenile turbot, Scophthalmus maximus (Rafinesque). Aquaculture. 1999;178(1):77-88.

113. Kristiansen TS, Fernö A, Holm JC, et al. Swimming behaviour as an indicator of low growth rate and impaired welfare in Atlantic halibut (Hippoglossus hippoglossus L.) reared at three stocking densities. Aquaculture. 2004;230(1):137-151.

114. Herrera M, Vargas-Chacoff L, Hachero I, et al. Physiological responses of juvenile wedge sole Dicologoglossa cuneata (Moreau) to high stocking density. Aquac Res. 200940(7):790-797.

115. Martinez-Tapia C, Fernandez-Pato C. Influence of stock density on turbot (Scophthalmus maximus L.) growth. ICES. 1991;CM1991/F:20-27.

116. Salas-Leiton E, Anguis V, Manchado M, et al. Growth, feeding and oxygen consumption of Senegalese sole (Solea senegalensis) juveniles stocked at different densities. Aquaculture. 2008;285(1):84-89.

117. Barcellos L, Nicolaiewsky S, De Souza S, et al. The effects of stocking density and social interaction on acute stress response in Nile tilapia Oreochromis niloticus (L.) fingerlings. Aquac Res. 1999;30(11-12):887-892.

118. Montero D, Izquierdo M, Tort L, et al. High stocking density produces crowding stress altering some physiological and biochemical parameters in gilthead seabream, Sparus aurata, juveniles. Fish Physiol Biochem. 1999;20(1):53-60

119. Ellis T, North B, Scott A, et al. The relationships between stocking density and welfare in farmed rainbow trout. J Fish Biol. 2002;61(3):493-531.

120. Björnsson B, Ólafsdóttir SR. Effects of water quality and stocking density on growth performance of juvenile cod (Gadus morhua L.). ICES J Mar Sci. 2006;63(2):326-334.

121. Papoutsoglou SE, Karakatsouli N, Pizzonia G, et al. Effects of rearing density on growth, brain neurotransmitters and liver fatty acid composition of juvenile white sea bream Diplodus sargus L. Aquac Res. 2006;37(1):87-95.

122. North B, Turnbull J, Ellis T, et al. The impact of stocking density on the welfare of rainbow trout (Oncorhynchus mykiss). Aquaculture. 2006;255(1):466-479.

123. Vijayan M, Ballantyne J, Leatherland J. High stocking density alters the energy metabolism of brook charr, Salvelinus fontinalis. Aquaculture. 1990;88(3):371-381.

124. Di Marco P, Priori A, Finoia M, et al. Physiological responses of European sea bass Dicentrarchus labrax to different stocking densities and acute stress challenge. Aquaculture. 2008;275(1):319-328.

125. Vazzana M, Cammarata M, Cooper E, et al. Confinement stress in sea bass (Dicentrarchus labrax) depresses peritoneal leukocyte cytotoxicity. Aquaculture. 2002;210(1):231-243. 
126. Kotani $\mathrm{T}$, Wakiyama $\mathrm{Y}$, Imoto $\mathrm{T}$, et al. Improved larviculture of ocellate puffer Takifugu rubripesthrough control of stocking density. Aquaculture. 2011312(1):95-101.

127. Wendelaar Bonga SE. The stress response in fish. Physiol Rev. 1997;77(3):591-625.

128. Pickering AD, Pottinger TG. Poor water quality suppresses the cortisol response of salmonid fish to handling and confinement. J Fish Biol. 1987;30(3):363-374.

129. Kihslinger R, Lema SC, Nevitt G. Environmental rearing conditions produce forebrain differences in wild Chinook salmon Oncorhynchus tshawytscha. Comp Biochem Physiol A Comp Physiol. 2006;145(2):145151.

130. Marchetti MP, Nevitt GA. Effects of hatchery rearing on brain structures of rainbow trout, Oncorhynchus mykiss. Environ Biol Fishes. 2003;66(1):9-14.

131. Näslund J, Johnsson JI. Environmental enrichment for fish in captive environments: effects of physical structures and substrates. Fish Fish. $2014 ; 17: 1-30$.

132. Horn M. Feeding and digestion. In: Evans DH (Ed.), The Physiology of Fishes. CRC press, Boca Raton, FL, USA. 1998;pp.43-63.

133. Dabrowski K, Portella M. Feeding plasticity and nutritional physiology in tropical fishes. In: Val AL, Val VMFdAe, Randall DJ (Eds.), Fish Physiology, The Physiology of Tropical Fishes. Academic press, USA. 2005;pp.155-224.

134. López-Vásquez K, Castro-Pérez C, Val A. Digestive enzymes of eight Amazonian teleosts with different feeding habits. J Fish Biol. 2009;74(7):1620-1628.

135. Yahashi S, Kang KS, Kaiya $\mathrm{H}$, et al. GHRP-6 mimics ghrelin-induced stimulation of food intake and suppression of locomotor activity in goldfish. Peptides. 2012;34(2):324-328

136. Hara T. Feeding behaviour in some teleosts is triggered by single amino acids primarily through olfaction. J Fish Bio. 2006;68(3):810-825.

137. New JG. Multimodal integration in the feeding behaviors of predatory teleost fishes. Brain Behav Evol. 2002;59:177-189.

138. Valentinčič T, Caprio J. Visual and chemical release of feeding behavior in adult rainbow trout. Chem Senses. 1997;22(4):375-382.

139. Perez J, Zanuy S, Carrillo M. Effects of diet and feeding time on daily variations in plasma insulin, hepatic c-AMP and other metabolites in a teleost fish, Dicentrarchus labrax L. Fish Physiol Biochem. 1988;5(4):191-197.

140. Stirling H. Effects of experimental feeding and starvation on the proximate composition of the European bass Dicentrarchus labrax. Mar Biol. 1976;34(1):85-91

141. Stirling H. Growth, food utilization and effect of social interaction in the European bass Dicentrarchus labrax. Mar Biol. 1977;40(2):173-184.

142. C Carrillo M, Zanuy S, Herrera E. Growth and diurnal variations in metabolic parameters in the starved bass, Dicentrarchus labrax, after experimental feeding. Comp Biochem Physiol A Comp Physiol. 1982;72(1):11-16.

143. Gutiérrez J, Carrillo M, Zanuy S, et al. Daily rhythms of insulin and glucose levels in the plasma of sea bass Dicentrarchus labrax after experimental feeding. Gen Comp Endocrinol. 1984;55(3):393-397.

144. Pearson TH, Black KD. The environmental impacts of marine fish cage culture. In: Black KD (Eds.), Environmental Impacts of Aquaculture. Sheffield Academic Press, Sheffield, USA. 2001;pp.1-31.
145. Yokoyama H, Takashi T, Ishihi Y, Abo K. Effects of restricted feeding on growth of red sea bream and sedimentation of aquaculture wastes. Aquaculture. 2009;286(1):80-88.

146. McCarthy I, Carter C, Houlihan D. The effect of feeding hierarchy on individual variability in daily feeding of rainbow trout, Oncorhynchus mykiss (Walbaum). J Fish Biol. 1992;41(2):257-263.

147. Talbot C, Corneillie S, Korsøen Ø. Pattern of feed intake in four species of fish under commercial farming conditions: implications for feeding management. Aquac Res. 1999;30(7):509-518.

148. Spieler RE. Diel and seasonal changes in response to stimuli: a plague and a promise for mariculture. Proceedings of the annual meeting-World Mariculture Society. 1977;8:865-882.

149. Delahunty G, Olcese J, Prack M, et al. Diurnal variations in the physiology of the goldfish, Carassius auratus. Biol Rhythm Res. 1978;9(2):73-88.

150. Sundararaj BI, Nath P, Halberg F. Circadian meal timing in relation to lighting schedule optimizes catfish body weight gain. J Nutr. 1982;112(6):1085-1097.

151. Noeske TA, Spieler RE. Circadian feeding time affects growth of fish. $T$ Am Fish Soc. 1984;113(4):540-544.

152. Jönsson E. The role of ghrelin in energy balance regulation in fish. Gen Comp Endocrinol. 2013;187:79-85.

153. Amole N, Unniappan S. Fasting induces preproghrelin mRNA expression in the brain and gut of zebrafish, Danio rerio. Gen Comp Endocr. 2009;161(1):133-137.

154. Unniappan S, Canosa LF, Peter RE. Orexigenic actions of ghrelin in goldfish: feeding-induced changes in brain and gut mRNA expression and serum levels, and responses to central and peripheral injections. Neuroendocrinology. 2004;79(2):100-108

155. Miura T, Maruyama K, Shimakura S, et al. Neuropeptide Y mediates ghrelin-induced feeding in the goldfish, Carassius auratus. Neurosci Lett. 2006;407(3):279-283.

156. Kang KS, Yahashi S, Matsuda K. The effects of ghrelin on energy balance and psychomotor activity in a goldfish model: an overview. Int J Pept. 2011;2011:1-9.

157. Matsuda K, Miura T, Kaiya H, et al. Stimulatory effect of n-octanoylated ghrelin on locomotor activity in the goldfish, Carassius auratus. Peptides. 2006;27(6):1335-1340

158. Sánchez-Vázquez F, Madrid J, Zamora S, et al. Feeding entrainment of locomotor activity rhythms in the goldfish is mediated by a feedingentrainable circadian oscillator. J Comp Physiol A. 1997;181(2):121132

159. Falahatkar B, Poursaeid S, Shakoorian M, et al. Responses to handling and confinement stressors in juvenile great sturgeon Huso huso. J Fish Biol. 2009;75(4):784-796

160. Afonso L, Hosoya S, Osborne J, et al. Lack of glucose and hsp70 responses in haddock Melanogrammus aeglefinus (L.) subjected to handling and heat shock. J Fish Biol. 2008;72(1):157-167.

161. Braun N, de Lima RL, Baldisserotto B, et al. Growth, biochemical and physiological responses of Salminus brasiliensis with different stocking densities and handling. Aquaculture. 2010;301(1):22-30.

162. Gomes LdC. Physiological responses of pirarucu (Arapaima gigas) to acute handling stress. Acta Amaz. 2007;37(4):629-633. 